\title{
Congress sees instability in Russia as threat to space station deal
}

Washington. Congressional supporters of the space station being planned by the $\mathrm{Na}$ tional Aeronautics and Space Administration (NASA) are becoming increasingly alarmed that, having become reliant on full Russian participation, the station could quickly fall victim to political instability in Russia following the recent elections.

Their strong support is needed to continue US annual funding of $\$ 2$ billion for the project. But the Congressmen are angry at the Clinton administration for rushing forward with plans for the Russian collaboration. They feel that the plans are short on detail, and vulnerable to a host of uncertainties, highlighted by the recent Russian election results.

George Brown, chairman of the House of Representatives' Science, Space and Technology Committee and a key space station supporter, claims that both the White House and NASA lack the staff and expertise needed to manage the huge, complex and speedy collaboration now being proposed with the Russians.

"We've moved rather precipitously into this engagement," says Brown. "It's not the engagement, but the depth of analysis that bothers me. We have taken on something which may be beyond the scope of what we understand."

Brown, who has just returned from a visit

to the site at Baikonur in Kazakhstan from which Russian components of the space station would be launched, says that he is in favour of more co-operation with Russia, but wants it to be co-operation which will succeed. "We may be getting into a situation here which is doomed to run into problems," says Brown.

$\mathrm{He}$ adds that "any single failure" will now kill the station in the House, which last year

\section{IMAGE UNAVAILABLE FOR COPYRIGHT REASONS} voted to continue it by a wafer-thin 216-215 margin. "If Russia falls out the station will go down, just as it will if there is any re-estimate of the costs."

Goldin: under pressure from Congress

Some of those who accompanied Brown to Kazakhstan complain privately that director Yuri Koptev, the director of the Russian Space Agency (RSA), was unable to provide any solid information on how the proposed collaboration would work.

The mission found the launch site virtually deserted. The rocket launch pads were in good repair, but the surrounding infrastructure is in need of "substantial upgrad-

\section{Canadian science gets Nobel gift}

Ottawa. Michael Smith, the British-born Canadian chemist who won this year's Nobel prize for his work on site-directed mutagenisis (Nature 365, 684; 1993), announced last week that he is to donate half of his Can $\$ 500,000$ (US\$380,000) prizemoney to support basic research into brain function and in particular the origins of schizophrenia.

The other half of the prize-money will be used to help attract more young people, especially women, to pursue scientific studies, and to create a "better public awareness of science in Canada".

Speaking at a dinner held in his honour by the Medical Research Council (MRC) of Canada, which has supported his research for 28 years, Smith said that he had personal reasons for being interested in schizophrenia. But he added that he was also confident that research on the brain will eventually help solve many human diseases, from manic depression to Parkinson's disease.

The MRC's response to Smith's gift has been to create the Michael Smith Award of
Excellence, consisting of a medal and Can $\$ 50,000$, which will be awarded each year for "exceptional creativity and innovation in health research".

The council will support one graduate studentship, one postdoctoral fellowship and one new faculty salary award, totalling more that Can $\$ 775,000$, for individuals whose research focuses on the molecular genetics of brain disorders. It will also work with the Schizophrenia Society of Canada and the pharmaceutical industry to establish a research chair on schizophrenia.

The federal Department of Industry has also responded with a Can $\$ 500,000$ commitment for the promotion of science, while the British Columbia government has established a Can\$1 million endowment for schizophrenia research and science promotion. For their part, the Schizophrenia Society of Canada and the Canadian Alliance for Research on Schizophrenia have jointly promised to raise a Can $\$ 1$ million endowment for research training in schizophrenia. ing", says Brown, estimating that this might cost around $\$ 100$ million.

Meanwhile Koptev and Dan Goldin, the administrator of NASA, signed a space co-operation agreement covering collaborative missions to the Russian MIR space station. They hope this will lead to a formal agreement on the international space station proposed last month, to be launched by 12 Russian and 19 US shuttle missions from 1997.

Goldin claimed that the Russian involvement would enhance both the space station itself, and the chances of approval in Congress. "The president is very strongly behind it, as are key members of Congress," he said.

Goldin estimates that the US will probably pay Russia a total of "somewhat less than \$1 billion" for its help with the space station completion, including the $\$ 400$ million already promised in advance of station construction and launch. Further details of the station collaboration are due to be worked out at meetings this week between NASA and the RSA.

Asked about the prospects of yet further design changes, Goldin was emphatic that November's design proposal is the final one. "This is it," he said. "We do not want to spend one single minute more on redesign."

Space analysts are optimistic about the space station's funding prospects, largely because of the Clinton administration's firm backing and associated decision to reposition the project as a central pillar of its policy towards Russia (Nature 365, 681; 1993).

"At least this has attracted high level White House interest," says John Pike of the Federation of American Scientists. "Clinton has re-established a geopolitical place for the space station." Pike says that some dependence on Russia was inevitable if the Russian contribution was to be great enough to hold down US costs and thus secure congressional support.

Pike observes that if the United States is worried that the space station is just one Russian coup away from a speedy and final demise, then Russia is entitled to point out that just one vote in the US Congress could kill it too. Perhaps that has both parties suitably reassured: it certainly leaves their lesser partners - Japan, Canada and Europe - betting on an interesting double.

But as the Clinton administration, including Admiral Bobby Inman, the new Secretary of Defense, moves hastily to revise its entire foreign policy in the wake of the Russian election results, all bets may soon be off. 